\title{
Patients' beliefs about adherence to oral antidiabetic treatment: a qualitative study [Corrigendum]
}

Guénette L, Lauzier S, Guillaumie L, Giguère G, Grégoire JP, Moisan J. Patient Prefer Adherence. 2015;9:413-420.

On page 414, Data collection and variables section, 1st paragraph, "We used a modified version of the validated French version ${ }^{18}$ of the 4-item Morisky medication adherence scale (MMAS-4). ${ }^{19}$ " should have been "We used a modified version of the validated French version ${ }^{18}$ of a 4 -item selfreport medication adherence scale (SR-4). ${ }^{19}$ ",

On page 415, Results section, 1st paragraph, "Based on the MMAS-4, 18 participants (40\%) were considered adherent (score $=4 / 4$ ) and the mean score was 3.16/4." should have been "Based on the SR-4, 18 participants (40\%) were considered adherent (score $=4 / 4$ ) and the mean score was 3.16/4."
On page 415, Table 1, the last column heading should have been "Adherent according to SR-4." The Abbreviation list for this table should have been "Abbreviation: SR-4, 4-item self-report medication adherence scale".

On page 416, Results section, last paragraph, "Forgetfulness was also observed in the MMAS-4 results. Among the 27 nonadherent participants, 17 (63\%) identified forgetfulness (the first question in the MMAS-4 questionnaire) as the only reason for being nonadherent." should have been "Forgetfulness was also observed in the SR-4 results. Among the 27 nonadherent participants, 17 (63\%) identified forgetfulness (the first question in the SR-4 questionnaire) as the only reason for being nonadherent."
Patient Preference and Adherence

\section{Publish your work in this journal}

Patient Preference and Adherence is an international, peer-reviewed, open access journal that focuses on the growing importance of patient preference and adherence throughout the therapeutic continuum. Patient satisfaction, acceptability, quality of life, compliance, persistence and their role in developing new therapeutic modalities and compounds to optimize

\section{Dovepress}

clinical outcomes for existing disease states are major areas of interest for the journal. This journal has been accepted for indexing on PubMed Central. The manuscript management system is completely online and includes a very quick and fair peer-review system, which is all easy to use. Visit http://www. dovepress.com/testimonials.php to read real quotes from published authors. 